\title{
Primary oxide spillover DL pseudo-capacitance charging and discharging in the light of the first principle theory
}

\begin{abstract}
Due to the irreversible disproportionation of the primary (Pt-OH), into much more stable surface $(P t=O)$ oxide, all plain $(P t)$ and non-interactive supported $(P t / C)$ noble metals, within a wider (more than $600 \mathrm{mVs}$ ) potential range between hydrogen and oxygen evolving limits are deprived from the former, and thereby behave partially, but broadly polarizable. Since almost all interactive catalytic hypo-d-oxide supports in wet hydrated state feature continuous and renewable latent storage and spillover of the Pt-OH, such composite catalysts $\left(\mathrm{Pt}_{\mathrm{W}} \mathrm{WO} \mathrm{O}_{3}, \mathrm{TiO}_{2}\right)$ enable provided the reversible electrocatalytic properties for the oxygen electrode reactions. Potentiodynamically the latter consists in almost unlimited and reversible DL pseudo-capacitor charging and discharging within the whole potential range in between of oxygen and hydrogen evolving limits. To comfirm such DL properties, based and consisted in the Pt-OH dipole spillover, the rigorous First principle analysis has been carried out and yielded with relevant interrelations of broader significance.

Keywords: First Principle; spillover; SMSI \{Strong Metal-(Hypo-d-(f)-Oxide) Support Interaction\}, primary $(\mathrm{Pt}-\mathrm{OH})$ oxide, surface $(\mathrm{Pt}=\mathrm{O})$ oxide, $\mathrm{DL}$ charging and/or discharging of double layer pseudocapacitance, work function $(\Delta \Phi)$; electrocatalysis; heterogeneous catalysis
\end{abstract}

\section{INTRODUCTION}

Ever since Sir William Grove invented fuel cells (FCs) [1], electrocatalysts of the reversible oxygen electrode (ROE) properties became the main imperative target, challenge and dream in the whole electrochemical science of aqueous and later PEM media. The main focus has always primarily been posed on noble (Pt,Au) metals, while the reversible primary $(\mathrm{Pt}-\mathrm{OH}, \mathrm{Au}-\mathrm{OH})$, and polarizable surface $(\mathrm{Pt}=\mathrm{O}, \mathrm{Au}=\mathrm{O})$ oxides, along with $\mathrm{H}$-adatoms $(\mathrm{Pt}-\mathrm{H}, \mathrm{Au}-\mathrm{H})$ represent interactive species defining the overall electrode behavior and properties. In such a respect potentiodynamic spectra, (Fig. 1), usually reveal within a narrow potential range the highly reversible peaks of primary oxide adsorptive growth and its backwards desorptive removal [2,3], as a typical double layer

$$
\mathrm{Pt}+2 \mathrm{H}_{2} \mathrm{O} \leftrightarrow \mathrm{Pt}-\mathrm{OH}+\mathrm{H}_{3} \mathrm{O}^{+}+e^{-}
$$

\footnotetext{
${ }^{*}$ Corresponding author: Jelena Jaksic

E-mail: jelena@iceht.forthe.gr

Paper received: 10. 01. 2016.

Paper accepted: 20. 02. 2016.

Paper is available on the website:

www.idk.org.rs/journal
}

(DL) charging and discharging pseudo-capacitance [4-7], while the former soon later irreversibly disproportionates into the strongly polarizable, more adsorptive and remarkably more stable surface oxide $(\mathrm{Pt}=\mathrm{O})$ monolayer [2,3],

$$
\mathrm{Pt}-\mathrm{OH}+\mathrm{H}_{2} \mathrm{O} \rightarrow \mathrm{Pt}=\mathrm{O}+\mathrm{H}_{3} \mathrm{O}^{+}+e^{-}
$$

with the corresponding pronounced irreversible desorption peak all along the equivalent reverse potential scan direction, back and forth. The former, (Eq. 1), arises as the highly reversible reaction, proceeds independently and extremely fast, while the latter, (Eq. 2), as a typical irreversible disproportionation reaction step, is rather slow and highly polarizable. Such state of the experimental evidence, reveals and definitely defines electrocatalytic fate and properties of almost all plain $\mathrm{Pt}(\mathrm{Au})$, and non-interactive $(\mathrm{Pt} / \mathrm{C}$, $\mathrm{Au} / \mathrm{C}$ ) supported noble, and majority of hyper-delectron $(n \geq 5)$ metals within transition series. In such circumstances, there is no d-metal which might feature electrocatalytic properties all along the potential axis between hydrogen and oxygen evolving limits, but partially reversible and partially polarizable. Thus, from thermodynamic definition, no one metal in the Periodic Table is fully 
reversible for the oxygen electrode reactions, but each of them more or less irreversible or polarizable.

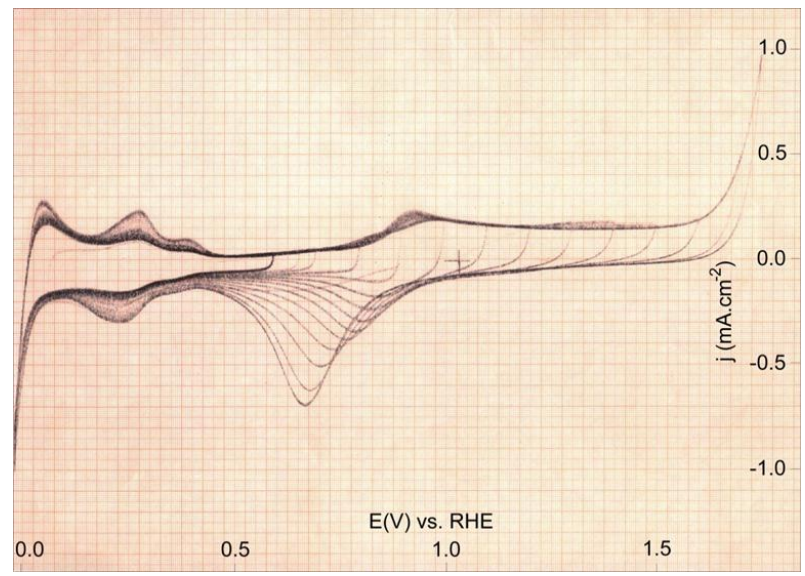

Figure 1 - Cyclic voltammograms of polycrystalline Pt scanned in $0.1 \mathrm{M} \mathrm{NaOH}$ at sweep rate $100 \mathrm{mV}^{-1} \mathrm{~s}^{-1}$

In fact, in the absence of the Pt-OH, therefrom imposes such a critical and typical, very pronounced the reaction polarization range (Fig. 1), all along until oxygen potential evolving limits, and in both scan directions, back and forth [4-7]. Such highly reversible (Eq. 1), relative to the subsequent strongly irreversible, and substantially polarizable (Eq. 2) transient and coexistence of two interrelated reaction steps, has been decisive as concerns the overall electrocatalytic properties and behavior of both $\mathrm{Pt}$ and $\mathrm{Au}$, and all other noble and even many non-noble transition metal electrodes for the oxygen electrode reactions \{cathodic oxygen reduction (ORR) and anodic oxygen evolution OER)\}. Since the equimolar ratio of the primary and surface oxide concentrations defines the optimal interfering self-catalytic spillover reaction step in cathodic oxygen reduction reaction ++mechanism (ORR) [8],

$\mathrm{Pt}-\mathrm{OH}+\mathrm{Pt}=\mathrm{O}+3 \mathrm{H}_{3} \mathrm{O}^{+}+3 e^{-} \rightarrow 5 \mathrm{H}_{2} \mathrm{O}+2 \mathrm{Pt}$

and in particular along the reversible (low slope, 30 $\mathrm{mV} / \mathrm{dec}$, or even lower) parts of Tafel line plots, the irreversible disproportionation (Eq. 2) imposes an extremely high reaction polarization barrier that amounts for even more than $600 \mathrm{mVs}$ and then, in absence of the $\mathrm{Pt}-\mathrm{OH}$, makes plain $\mathrm{Pt}$ (and $\mathrm{Au}$ ) and non-interactive supported both $(\mathrm{Pt} / \mathrm{C}$ or $\mathrm{Au} / \mathrm{C})$ platinum and gold irreversible for the oxygen electrode reactions within the broader potential range, back and forth. The thermodynamic definition of irreversibility then would state that plain $\mathrm{Pt}(\mathrm{Au})$ by no means can feature the reversibility and/or (electro)catalytic activity all along the potential range in aqueous media. In other words, plain and non-interactive $(\mathrm{Pt} / \mathrm{C}$ and/or
$\mathrm{Au} / \mathrm{C})$ supported $\mathrm{Pt}(\mathrm{Au})$ electrodes themselves by no means can behave electrocatalytic features of the reversible oxygen electrode (ROE) all along the potential axis between hydrogen and oxygen evolving limits. The strongly adsorptive and thence highly polarizable $\mathrm{Pt}=\mathrm{O}(\mathrm{Au}=\mathrm{O})$, deprived from any local and/or the external Pt-OH (Au-OH) source and supply, then defines one of the most pronounced issues of the reaction polarization in the entire electrochemical science: No $\mathrm{Pt}-\mathrm{OH}$, means that there is no reversible reaction (Eq. 3). Quite another story arises when nanostructured $\mathrm{Pt}(\mathrm{Au})$ electrocatalyst is interactive selective grafting bonded on various, in particular mixed valence hypo-d-(f)-oxide supports.

Whereas hydrogen molecules undergo spontaneous, and thence reversible adsorptive dissociation on plain $\mathrm{Pt}(\mathrm{Pt} / \mathrm{C})$, yielding $\mathrm{H}$-adatoms $(\mathrm{Pt}-\mathrm{H})$ to establish thermodynamic equilibrium of the RHE (Reversible Hydrogen Electrode, $\left.\left(\mathrm{Pt}\left(\mathrm{H}_{2}\right) / \mathrm{Pt}-\mathrm{H} / \mathrm{H}_{3} \mathrm{O}^{+}\right)\right)$, within the above identified critical potential range $\mathrm{Pt}(\mathrm{Au})$ is deprived (Eq. 2), from the $\mathrm{Pt}-\mathrm{OH}$ (Au-OH) to provide reversible properties for the $\mathrm{ROE}\left(\left(\mathrm{Pt}\left(\mathrm{O}_{2}\right) / \mathrm{Pt}-\mathrm{OH}, \mathrm{Pt}=\mathrm{O}\right) / \mathrm{OH}^{-}\right)$, (Eq. 3), and both together assemble the reversible hydrogen fueled L\&MT (Low amd Medium Temperature) PEMFCs. In other words, the $\mathrm{Pt}-\mathrm{OH}$ (or $\mathrm{Au}-\mathrm{OH}$ ) plays the same thermodynamic constitutional role for establishing the equilibrium for the ROE, as Pt-H does for the RHE, and thence, unavoidably imposes continuous need and requires a permanent source of the former to overcome the reaction polarization by the latter, and enables the reversible electrocatalytic properties of the ROE $[6,7]$. The substance is that $\mathrm{Pt}-\mathrm{OH}(\mathrm{Au}-\mathrm{OH})$ is insoluble in aqueous media and represents surface species able only for heterogeneous reactions and spillover spreading. Thus, to learn and define behavior and properties of the primary oxides $(\mathrm{Pt}-\mathrm{OH}, \mathrm{Au}-\mathrm{OH})$ for $\mathrm{DL}$ charging and overall adsorptive and interactive features, one indispensably needs the First Principle search and analysis.

\section{MEMBRANE PROPERTIES OF CATALYTIC HYPO-D-OXIDE SUPPORTS}

In such a respect, the first main step in the concept towards the ROE implies that catalytic hyper-d-metals ( $\mathrm{Pt}, \mathrm{Au}, \mathrm{Ru})$ establish with hypo-d(f)-oxides (or their mixed valence compounds, like $\mathrm{Nb}_{2} \mathrm{O}_{5}, \mathrm{TiO}_{2}, \mathrm{CeO}_{2}$ or $\left.\mathrm{Ta}_{2} \mathrm{O}_{5}, \mathrm{TiO}_{2}, \mathrm{CeO}_{2}\right)$ the interactive Brewer type ( $d-d$ or $d-f$ ) bonding effect $[9,10]$, otherwise well known in heterogeneous catalysis as Tauster [11-13] SMSI (Strong MetalSupport Interaction), one of the strongest in the entire chemistry (Fig.3 in ref. [4]) [5]. Consequently, this way interactive inter-bonded composite electrocatalysts (example, $\mathrm{Pt} / \mathrm{Nb}_{2} \mathrm{O}_{5}, \mathrm{TiO}_{2}$ ), while 
strong bonding, impose remarkably stretched $d$ orbitals, and thereby exhibit much weaker adsorptive inter-bonding strengths of intermediates $(\mathrm{Pt}-\mathrm{H}, \mathrm{Pt}-\mathrm{OH})$ in the RDSs (Rate Determining Steps), thence correspondingly facilitated cleavage of the latter, and thereby, increased the catalytic activity both for hydrogen and oxygen electrode reactions. Meanwhile, some other accompanying effects, in particular the ones associated with the $\mathrm{Pt}-\mathrm{OH}$ spillover, play even more significant role for the latter. In such a respect, the dramatically pronounced $\mathrm{Pt}-\mathrm{OH}$ spillover effect has earlier and primarily been noticed as the remarkable increased CO-tolerance (Fig.7 in ref. [4]). First, hypo-d-oxides and their mixed valence compounds, as based on

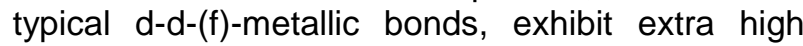
stability in both acidic and alkaline media, and many of them pronounced (above $300 \mathrm{~S} / \mathrm{cm}$ ) electron conductivity (Magneli phases even approaching 1,000 S/cm). Furthermore, majority of hypo-d-(f)-oxides and in particular of higher altervalent numbers, feature prevailingly high percentage of dissociative water molecules adsorption [14,15], (Eq.(1-a)), and thence, the mostly enhanced surface membrane type of hydroxyl ions migration mass transfer [16-18], (Eq. (1-b) and (1-c)),

$$
\begin{aligned}
& \mathrm{Nb}_{2} \mathrm{O}_{5}+5 \mathrm{H}_{2} \mathrm{O} \leftrightarrow 2 \mathrm{Nb}(\mathrm{OH})_{5} \\
& \mathrm{Nb}(\mathrm{OH})_{5}+\mathrm{Pt} \rightarrow \mathrm{Nb}(\mathrm{OH})^{4+}+\mathrm{M}-\mathrm{OH}+e^{-} \\
& \mathrm{Nb}(\mathrm{OH})^{4+}+2 \mathrm{H}_{2} \mathrm{O} \rightarrow \mathrm{Nb}(\mathrm{OH})_{5}+\mathrm{H}_{3} \mathrm{O}^{+}
\end{aligned}
$$

$$
\sum \mathrm{Pt}+2 \mathrm{H}_{2} \mathrm{O} \leftrightarrow \mathrm{Pt}-\mathrm{OH}+\mathrm{H}_{3} \mathrm{O}^{+}+\mathrm{e}^{-}
$$

ending up with the prevailing electron transfer to the interactive supported metallic catalyst, so that the Pt-OH behaves as a pronounced dipole species [19], and thus, exhibits the strong spillover surface repulsion, transfer and distribution. At the same time, the highly pronounced reversible potentiodynamic peaks testify for the extremely fast overall spillover reaction (Eq. 1), in both directions $[2,3]$, primarily used for DL charging and discharging, and then being ready and available for fast heterogeneous electrocatalytic reactions. Such an oxide network, in particular of polyvalent (high altervalent capacity) hypo-d-elements, when in hydrous state, behaves as an ion exchange membrane [16-18]. In fact, gels (aero and xerogels) are biphasic systems in which solvent molecules are trapped inside an oxide network, and such a material can be considered as a water-oxide membrane composite [16-18]].

In such an overall constellation, individual hypo-d-(f)-oxides, and even more so their mixed valence composite compounds, when in expanded (sol-gel synthesis with thorough liquid $\mathrm{CO}_{2}$ supercritical drying) hydrated surface state (Fig. 2), behave as unlimited latent storage and spillover sources of the primary oxide [4-7,20,21], continuously being renewed and recovered simply by water vapor supply and instantaneously proceeding with spontaneous dissociative adsorption of water molecules.

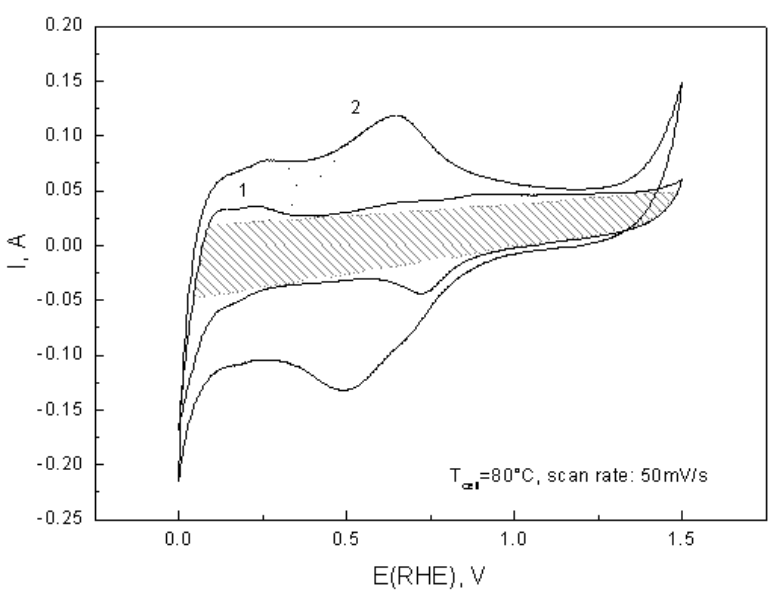

Figure 2 - Cyclic voltammograms of interactive (SMSI) supported nanostructured Pt electrode ( $\mathrm{Pt} / \mathrm{WO}_{3}, \mathrm{TiO}_{2} / \mathrm{C}$ ), on mixed valence hypo-d-oxides, scanned in He stream, ones at negligible moisture content (curve 1) and at $80^{\circ} \mathrm{C}$ water vapor saturation (curve 2)

\section{FIRST PRINCIPLE CONSIDERATION AND ANALYSIS}

The overall summation $(\Sigma)$ for the ion exchange properties of hypo-d-oxide hydrated membrane transferring matrix, under directional electric field effect or polarization, yields the reversible $\mathrm{Pt}-\mathrm{OH}$ adsorptive and/or desorptive spillover upon, or from metal electrocatalyst reactive surface, resulting that way with the characteristic pronounced reversible effusion peaks of extremely fast electrode reaction [2-7], (Eq. 1-a, 1-b and 1-c, yielding by such a summation the same former Eq. 1),

$$
\mathrm{M}+\mathrm{H} 2 \mathrm{O} \Leftrightarrow \mathrm{M}-\mathrm{OH}+\mathrm{H}++e^{-}
$$

The starting first principle thermodynamic relation for such a SMSI (exampled as $\mathrm{M} / \mathrm{TiO}_{2}$ ) system and just defined general reversible peak reaction, Eq. 1, arises therefrom in the following form,

$$
\bar{\mu}_{\mathrm{H}^{+}}=-\Delta \mu_{\mathrm{M}-\mathrm{OH}}-\bar{\mu}_{\mathrm{e}}+\mu_{\mathrm{H}_{2} \mathrm{O}}+\mu_{\mathrm{M}}
$$

while from the main general self-explanatory relation for electrochemical potential definition,

$$
\bar{\mu}_{\mathrm{e}}=\mu_{\mathrm{e}}-e \varphi=\mu_{\mathrm{e}}-e \psi-e \chi
$$


and particularly for hydronium ion $\left(\mathrm{H}_{3} \mathrm{O}^{+}\right.$, abbreviated for simplification as $\mathrm{H}^{+}$), there from Eq. 5 further follows an alternative relation,

$$
\bar{\mu}_{H^{+}}=\mu_{H^{+}}-e \phi_{H^{+}}
$$

To avoid and eliminate electrochemical potentials $\left(\bar{\mu}_{\mathrm{H}^{+}}, \bar{\mu}_{\mathrm{e}}\right)$, by equalizing the right-hand sides of Eq. 4 and 6 , and replacing the corresponding value from Eq. 5, there straightforward yields the following relation,

$$
\begin{aligned}
& \mu_{H^{+}}=-\mu_{M-O H}+\mu_{M}+ \\
& +\mu_{H_{2} O}+e \varphi-\mu_{e}+e \varphi_{H^{+}}
\end{aligned}
$$

Meanwhile, since $\varphi=\varphi_{H^{+}}+\chi=\psi+\chi$, and thereby, $\varphi_{H^{+}}=\psi \chi$ there further follows,

$$
\begin{aligned}
& \mu_{H^{+}}=-\mu_{M-O H}+\mu_{e}+ \\
& +\mu_{M}+\mu_{H_{2} O}+2 e \psi+e \chi
\end{aligned}
$$

Finally, by taking the derivative of Eq. 7, because $\Delta \mu_{\mathrm{e}}=0$, and since $\mu_{\mathrm{M}}, \mu_{\mathrm{H} 2 \mathrm{O}}$, and $\psi=$ const., while $\Delta \mu_{\mathrm{H}}+\ll<\mathrm{e} \Delta \mathrm{X}$, there straightforward results,

$$
\Delta \mu_{(M-O H)}=e \Delta X
$$

exactly as cyclic voltammograms (Fig. 2) reveal: Every change in spillover of the $\mathrm{M}-\mathrm{OH}$, or of its chemical potential $[(\Delta \mu)] \downarrow(M-O H)$, as the driving force of the effusion, or, simply its concentration variations, corresponds to the increment of surface potential $(\Delta \mathrm{X})$, or the change in capacity of $\mathrm{DL}$ because of $\mathrm{M}-\mathrm{OH}$ dipole adsorption package, or desorption (as the spillover capacity), both of them being fast and substantially reversible, define $\mathrm{DL}$ charging or discharging (in its pseudo-capacity). Namely, since $\Delta \mu_{H}+$ is logarithmic function of hydronium ions concentration, and according to the spillover electrode reaction (Eq. 1), primary oxide $(\mathrm{M}-\mathrm{OH})$ and $\mathrm{H}_{3} \mathrm{O}^{+}$ions become simultaneously spent or produced in equivalent (1:1) amounts, while the contribution of surface energy is the linear function of surface potential (prevailing dipole effect), e $\Delta \chi$, then the inequality conclusion, $\Delta \mu H+<<e \Delta \chi$, emerges quite logically.

Since the fundamental definition of work function $(\Phi)$ states $[22,23]$ that

$$
e \Phi=-\mu_{\mathrm{e}}+e X
$$

and taking into account Eq. 9, by derivation of the latter (Eq. 10), there straight forward follows the broader fundamental relation for $\mathrm{M}-\mathrm{OH}$ spillover adsorption and/or desorption, which is the same as the DL pseudo-capacitance charging and/or discharging,

$$
e \Delta \Phi=e \Delta \chi=\Delta \mu_{\mathrm{M}-\mathrm{OH}}
$$

Simple combination of Eq. 10 with Eq. 5, then yields the alternative first principle relation between work function and electrochemical potential,

$$
\bar{\mu}_{\mathrm{e}}=-e \Phi-e \psi
$$

which, for the considered issue of electrochemical cell $\left(U_{W R}\right)$, assembled between working $(W)$ and stable reference (R) electrode, can be straightforward written to read,

$$
\bar{\mu}_{\mathrm{e}}=\Delta U_{\mathrm{WR}}=-e \Delta \Phi-e \Delta \psi
$$

The main contribution both to changes in work function $(\Delta \Phi)$ and primary oxide dipole spillover $(\Delta \mu M-O H)$, comes from the surface potential increment $(\Delta \mathrm{X})$ itself (Eq. 9), as the prevailing part of inner or Galvani potential $(\Delta \varphi)$. Namely, Vayenas et al. [24,25] have proved on plentiful systems in solid state electrolyte [26], aqueous media [27-29,] and PEM Nafion 112 [30] the basic NEMCA or EPOC promotion relation in heterogeneous catalysis,

$$
\Delta U_{W R}=e \Delta \Phi
$$

that could also be considered as fundamental both in electrode kinetics [31-33] and spillover phenomena [34]. Meanwhile, the latter (Eq. 14), when correlated with the preceding relation (Eq. 13), unambiguously and consequently yields that

$$
\Delta \psi=0 \text { or } \psi_{W}=\psi_{R}=\text { const. }
$$

which is also implied in above preceding equations (Eq. 8 and 9) $[35,36]$. Such conclusive and farreaching statement is in particular reliably clear for the electrode steady state and with high concentration supporting electrolyte.

The whole thermodynamic equilibrium for the general issue of interactive (SMSI) metal/hypo-doxide supported ${ }^{c}$ atalyst, such as $\mathrm{M} / \mathrm{TiO}_{2}$, is now illustratively displayed in all interconnected energy details by Fig. 11 in ref. 8. As a consequence, any decrease of the $\mathrm{M}-\mathrm{OH}$ chemical potential $[(\Delta \mu)] \downarrow(M-O H))$, causes te work function to decrease correspondingly, and vice versa. In other words, any consumption of adsorbed $\mathrm{M}-\mathrm{OH}$ upon metallic catalyst surface causes to decrease its chemical potential, and this way imposes imbalance within the established equilibrium. Thus, to keep constant both $\Delta \Phi$ and cell voltage between working $(\mathrm{W})$ and reference $(\mathrm{R})$ electrode $\left(\Delta \mathrm{U}_{\mathrm{WR}}\right)$, 
the titania phase, by its enriched latent storage of the primary oxide, automatically reacts by its membrane transferring mechanism and supplies hydroxide ions (Scheme I), to emanate further as the primary oxide spillover adsorptive species on

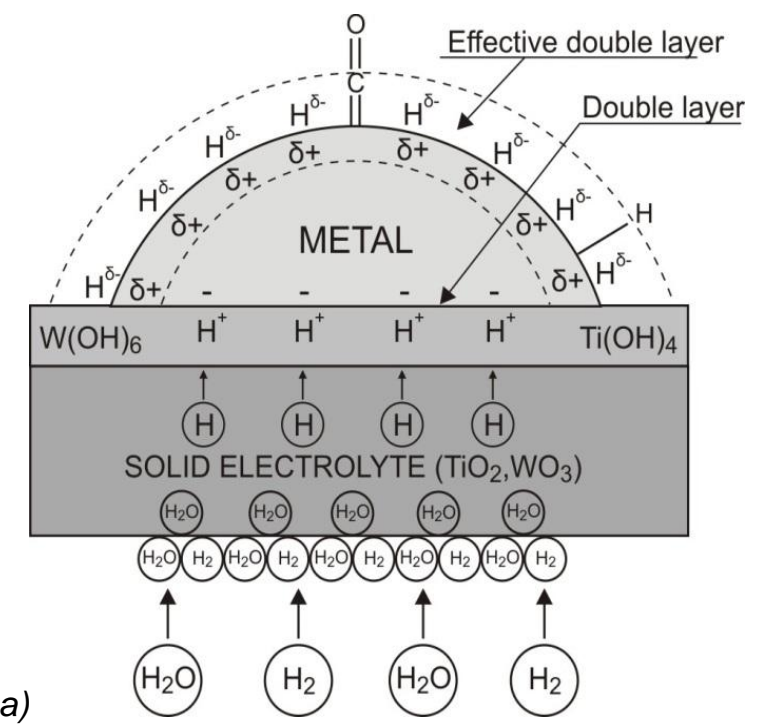

exposed metallic catalyst surface by corresponding electrocatalytic reaction (Eq. 1), both from hydrated anatase structure and [by reacting of continuously supplied water molecules.

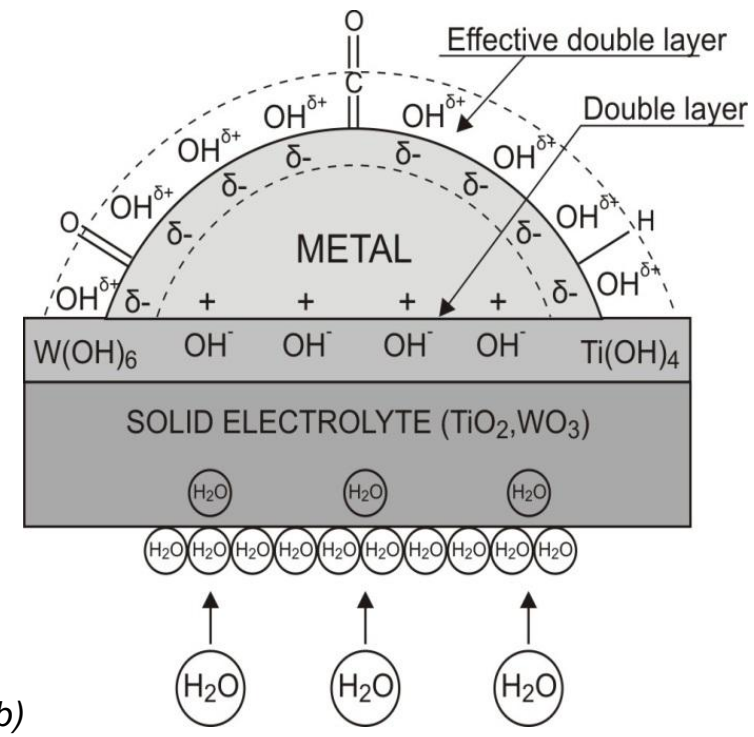

Scheme I - $a$ \& b. Model presentation for the SMSI effect, resulting in the spillover transfer of $\mathrm{H}$-adatoms within the bronze nanostructure $\left(\mathrm{Pt} / \mathrm{H}_{0.35} \mathrm{WO}_{3}\right.$, Scheme la), and/or the primary oxide $(\mathrm{M}-\mathrm{OH})$ effusion, as a

dipole along the hydrated counterpart $\left(\mathrm{Pt} / \mathrm{W}(\mathrm{OH})_{6}\right.$, Scheme lb), further continuously transferring them upon the metallic part (Pt) of catalyst, otherwise both originating from the hypo-d-oxide continuously fed by moisture stream to such a composite $\left(\mathrm{M} / \mathrm{TiO}_{2}, \mathrm{WO}_{3}\right)$ electrocatalyst structure and maintaining them in the reversible interchangeable equilibrium $\left(P t / H_{0.35} W_{3} \leftrightarrow P t / W(O H)_{6}\right)$, (constructed by Dimitris Tsiplakides).

The overall conclusion associated with otherwise broad experience in electrochemical promotion (NEMCA, EPOC) [22-25] of various chemical reactions in heterogeneous catalysis and particularly for Doebereiner (Ertl interpretation [37]) oxidation of hydrogen in water solutions, for catalysts interactive (SMSI) supported upon hypod-oxides, $\mathrm{OH}^{-}$- ions play the main membrane transferring and decisive promotion role, while $\mathrm{M}$ $\mathrm{OH}$, as defined dipole state, undertakes the spillover and features as the substantially reacting species all over the metallic catalyst surface, enabling that way to keep established such thermodynamic equilibrium. In fact, there is no catalytic promotion for hydrogen oxidation in acidic aqueous media and apparently hydroxide ions impose such a substantial promoting efficiency, in particular within the interfering $(600-900 \mathrm{mV}$ vs. $\mathrm{RHE}$ ) potential range, when NEMCA approaches promotion effects of two orders of magnitude $[26,27]$. Therefore, any disturbance of such an equilibrium, such as the consumption of spillover adsorbed $\mathrm{M}-\mathrm{OH}$ species $\left(\Delta \mu_{1}(\mathrm{M}-\mathrm{OH})\right)$, or simple imposition of an external polarization, as just analytically shown above, reflects as the driving force $\left(\Delta U_{W R}=e \Delta \Phi\right)$, and instantaneously tends to reestablish the former equilibrium, or to keep its steady state.

The present analysis is best reflected and proved by comparison of Fig. 1 and 2, once when missing $\mathrm{Pt}-\mathrm{OH}$ spillover $(\mathrm{Pt}-\mathrm{OH} \rightarrow 0, \mathrm{Pt}=\mathrm{O} \rightarrow 1$ ), and when enriched spillover enables enormous primary oxide adsorptive deposition and reverse desorption, exactly as big capacitors do, and when present all over potentiodynamic cycluses [4-7].

\section{Acknowledgements}

The present paper has been done at the Institute of Chemical Engineering Science, ICEHT/FORTH, Patras, Greece and is dedicated to the 30th anniversary of the Institute.

\section{REFERENCES}

[1] W.R.Grove (1842) On a gaseous voltaic battery, Philosophical Magazine, 2, 417-420.

[2] B.E.Conway (1995) Electrochemical oxide film formation at noble metals as a surface-chemical process, Prog. Surf. Sci., 49, 331-452.

[3] H.Angerstein-Kozlowska, B. E.Conway, W.B. A. Sharp (1973) The real condition of electrochemically oxidized platinum surfaces: Part I. Resolution of component processes, J. Electroanal. Chem., 43, 9-36. 
[4] J.M.Jaksic, N.V.Krstajic, Lj. M.Vracar, S.G. Neophytides, D. Labou, P.Falaras, M.M.Jaksic (2007) Spillover of primary oxides as a dynamic catalytic effect of interactive hypo-d-oxide supports, Electrochim. Acta, 53, 349-361.

[5] N.V.Krstajic, Lj.M.Vracar, V.R.Radmilovic, S.G. Neophytides, D. Labou, J.M.Jaksic, R.Tunold, P. Falaras, M.M.Jaksic (2007) Advances in interactive supported electrocatalysts for hydrogen and oxygen electrode reactions, Surf. Sci., 601, 19491966.

[6] G.D.Papakonstantinou, J.M. Jaksic, D. Labou, A. Siokou, M.M.Jaksic (2011) Spillover phenomena and their striking impacts in electrocatalysis for hydrogen and oxygen electrode reactions, Adv. Phys. Chem., 2011, 1-22, Article ID 412165 , (2011).

[7] M.M.Jaksic, G.A.Botton, G.D.Papakonstantinou, F. Nan, J.M.Jaksic (2014) Primary oxide latent storage and spillover enabling electrocatalysts with reversible oxygen electrode properties and the alterpolar revertible (PEMFC versus WE) cell, J. Phys. Chem., C, 118, 8723-8746.

[8] Y.Ma, P.B.Balabuena (2007) Designing oxygen reduction catalysts: Insights from metalloenzymes, Chem. Phys. Lett., 440, 130-133.

[9] L.Brewer (1968) Bonding and structures of transition metals, Science, 161, 115-122.

[10] M.M.Jaksic (2000) Hypo-hyper-d-electronic interactive nature of synergism in catalysis and electrocatalysis for hydrogen reactions, Electrochim. Acta, 45, 4085-4099.

[11] S.J.Tauster, S.C.Fung, R.T.K. Baker, J.A.Horsley (1981) Strong-interactions in supported-metal catalysts, Science, 211, 1121-1125.

[12] S.A.Stevenson (1987) Metal-support interaction in catalysis, Sintering and Redispersion, Van Nostrand, New York.

[13] G.L.Haller, D.E.Resasco (1989) Metal-support interaction: Group VIII metals and reducible oxides, in Advances in Catalysis, D. D. Eley, H. Pires, P. B. Weisz, Eds. Academic Press, San Diego, vol. 36, p. 173-235.

[14] A.Vittadini, A.Selloni, F.P.Rotzinger, M.Gratzel (1998) Structure and energetics of water adsorbed at $\mathrm{TiO}_{2}$ anatase (101) and (001) surfaces, Phys. Rev. Lett., 81, 2954-2957.

[15] M.Lazzeri, A.Vittadini, A.Selloni (2001) Structure and energetics of stoichiometric $\mathrm{TiO}_{2}$ anatase surfaces, Phys. Rev. B, 63, Article no.155409.

[16] J. Livage, M. Henry, C. Sanchez (1988) Sol-gel chemistry of transition metal oxides, Prog. Solid State Chem., 18, 259-341.

[17] P.Judeinstein, J.Livage (1991) Sol-gel synthesis of $\mathrm{WO}_{3}$ thin films, J. Mater. Chem., 1, 621-627.

[18] J. Livage, G. Guzman (1996) Aqueous precursors for electrochromic tungsten oxide hydrates, Solid State lonics, 84, 205-211.

[19] M.T.M.Koper, R.A.Van Santen (1999) Interaction of $\mathrm{H}, \mathrm{O}$ and $\mathrm{OH}$ with metal surfaces, J. Electroanal. Chem., 472, 126-136.
[20] Z.Awaludin, J.G.S.Moo, T.Okajima, T.Ohsaka (2013) $\mathrm{TaO}_{x}$ - capped Pt nanoparticles as active and durable electrocatalysts for oxygen reduction, J. Mater. Chem., A, 1, 14754-14765.

[21] K.Fugane, T.Mori, D.R. Ou, P.Yan, F.Ye, H. Yoshikawa, J.Drennan (2012) Improvement of cathode performance on $\mathrm{Pt}-\mathrm{CeO}_{\mathrm{x}}$ by optimization of electrochemical pretreatment conditions for PEMFC application , Langmuir, 28, 16692-16700.

[22] I.Riess, C.G.Vayenas (2003) Fermi level and potential distribution in solid electrolyte cells with and without ion spillover, Solid State lonics, 159, 313-329.

[23] S.Trasatti (1977) The Work Function in Electrochemistry. In Advances in Electrochemistry and Electrochemical Engineering, C. W. Tobias; $\mathrm{H}$. Goerischer, Eds., Interscience, New York, vol. 10, p. 213-321.

[24] C.G.Vayenas, S.Bebelis, C.Pliangos, S.Brosda, D.Tsiplakides (2001) Electrochemical Activation of Catalysis: Promotion, Electrochemical Promotion, and Metal-Support Interactions, Kluver Academic/ Plenum Publishers, New York.

[25] C.G.Vayenas, M.M.Jaksic, S.I.Bebelis, S.G. Neophytides (1996) The Electrochemical Activation of Catalytic Reactions. In Modern Aspects of Electrochemistry, J. O'M. Bockris, B. E. Conway, R. E. White, Eds.; Plenum Press, New York, vol. 29, p. 57-202

[26] C.G.Vayenas, S.Bebelis, S.Ladas (1990) The dependence of catalytic activity on catalyst work function, Nature, 343, 625-627.

[27] D.Tsiplakides, J.Nicole, C.G.Vayenas, Ch. Comninellis (1998) Work function and catalytic activity measurements of an $\mathrm{IrO}_{2}$ film deposited on YSZ subjected to in situ electrochemical promotion, J. Electrochem. Soc., 145, 905-908.

[28] S.Neophytides, D.Tsiplakides, P.Stonehart, M.M. Jaksic, C.G.Vayenas (1994) Electrochemical enhancement of a catalytic reaction in aqueous solution, Nature, 370, 45 - 47.

[29] S.G.Neophytides, D.Tsiplakides, P.Stonehart, M.M. Jaksic, C.G.Vayenas (1996) Non-faradaic electrochemical modification of the catalytic activity of $\mathrm{Pt}$ for $\mathrm{H}_{2}$ oxidation in aqueous alkaline media, $\mathrm{J}$. Phys. Chem., 100, 14803 - 14814.

[30] D.Tsiplakides, S.G.Neophytides, O.Enea, M.M. Jaksic, C.G.Vayenas (1997) Non-faradaic electrochemical modification of the catalytic activity of Ptblack electrodes deposited on Nafion 117 solid polymer electro;ytes, J. Electrochemical Soc., 144, 2072 - 2078.

[31] D.Tsiplakides, C.G.Vayenas (2001) Electrode work function and absolute potential scale in solid-state electrochemistry, J. Electrochem. Soc., 148, E189E202.

[32] D.Tsiplakides, D.Archonta, C.G.Vayenas (2007) Absolute potential measurements in solid and aqueous electrochemistry using two Kelvin probes and their implications for the electrochemical promotion of catalysts, Topics Catal., 44, 469-479. 
[33] S.Trasatti (1982) The concept of absolute electrode potential. An attempt at a calculation, J. Electroanal. Chem., 139, 1-13.

[34] J.Nicole, D.Tsiplakides, C.Pliangos, X.E.Verykios, Ch.Comninellis, C.G.Vayenas (2001) Electrochemical promotion and metal-support interactions, J. Catal., 204, 23-34.

[35] I.S.Metcalfe (2001) Electrochemical promotion of catalysts, I. Thermodynamic considerations, J. Catal., 199, 247-258.
[36] I.S.Metcalfe (2001) Electrochemical promotion of catalysts, II. The role of a stable spillover species and prediction of reaction rate modification, $\mathrm{J}$. Catal., 199, 259-272.

[37] S.Volkening, K.Bedurftig, K.Jacobi, J.Wintterlin, G.Ertl (1999) Dual path mechanism for catalytic oxidation of hydrogen on platinum surface, Phys. Rev. Lett., 83, 2672-2675.

\section{IZVOD}

\section{PUNJENJE I PRAŽNJENJE PSEUDO-KONDENZATORA ELEKTRIČNOG DVOJNOG SLOJA PRELIVANJEM PRIMARNOG OKSIDA U SVETLU TEORIJE PRVOG ZAKONA TERMODINAMIKE}

Usled ireverzibilne disproporcionacije primarnog $(P t-\mathrm{OH})$, u znatno stabilniji površinski $(P t=\mathrm{O})$ oksid, svi čisti (Pt) i neinteraktivno naneti (Pt/C) plemeniti metali, unutar šireg (više od $600 \mathrm{mV}$ ) potencijalnog intervala između granica katodnog razvijanja vodonika $i$ anodnog izdvajanja kiseonika, lišeni su prisustva ovog prvog (Pt-OH), i stoga se ponašaju delimično polarizabilno u širem opsegu potencijala. Budući da gotovo svi interaktivni hipo-d-oksidni katalitički nosači u svom vlažnom hidratnom stanju, ispoljavaju neprekidna i obnovljiva latentna svojstva skladištenja $i$ prelivanja primarnog (Pt-OH) oksida, takva vrsta kompozitnih (binarnih) katalizatora $\left(\mathrm{Pt}_{\mathrm{WO}}, \mathrm{TiO}_{2}\right)$, obezbeđuje reverzibilna elektrokatalitička svojstva za kiseonične elektrodne reakcije. Potenciodinamički ovo se sastoji u gotovo neograničenom i reverzibilnom punjenju i pražnjenju dvojnoslojnog (DL) pseudi-kondenzatora unutar čitavog potencijalnog opsega izmedju granica razvijanja kiseonika i vodonika. Da bi se dokazala i potvrdila takva električna dvojnoslojna svojstva, koja se zasnivaju i sastoje iz dipolnog Pt-OH prelivanja, izvedna je dosledna analiza posredstvim Prvog zakona termodinamike, koja je dovela do pouzdanih $i$ relevantnih medjuzavisnosti od šireg značaja.

KIjučne reči: Prvi zakon termodinamike; prelivanje; SMNM \{Snažan Metal-(Hipo-d-(f)-Oksidni) Nosač (uzajamnog) Međudelovanja\}; primarni (Pt-OH) oksid, površinski (Pt=O) oksid, DL (Dvojnoslojno punjenje (ili pražnjenje) pseudokapaciteta); Izlazni rad (funkcija izlaznog rada elektrona $(\Delta \Phi)$; elektrokataliza, heterogena kataliza.

\section{Naučni rad}

Rad primljen: 10. 01. 2016.

Rad prihvaćen: 20. 02.2016.

Rad je dostupan na sajtu: www.idk.org.rs/casopis 